Tranchenko L., Yavorska V. Management and promotion of business processes of regional tourism. Journal of Education, Health and Sport. 2021;11(05): 281-288. eISSN 2391-8306. DOI http://dx.doi.org/10.12775/JEHS.2021.11.05.029

https://apcz.umk.pl/czasopisma/index.php/JEHS/article/view/JEHS.2021.11.05.029

https://zenodo.org/record/5328489

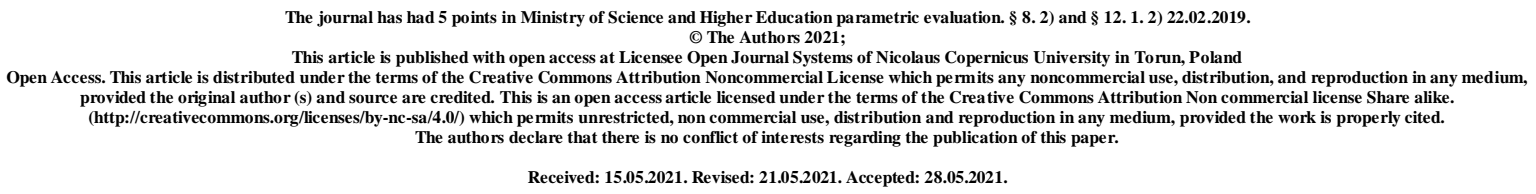

UDC 332:338.48

\title{
MANAGEMENT AND PROMOTION OF BUSINESS PROCESSES OF REGIONAL TOURISM
}

\author{
L. V. Tranchenko ${ }^{1}$, V. V. Yavorska ${ }^{2}$ \\ ${ }^{1}$ Uman National University of Horticulture, \\ ${ }^{2}$ Odesa I. I. Mechnikov National University
}

\begin{abstract}
Within the economy of different regions of Ukraine under modern conditions, tourism plays an increasingly important role. However, not all regions are able to provide long-term sustainable development of tourism on its territory. One of the main causes of problems in the development of regional tourism is the imperfection of the regional system of tourism management. This article discusses key issues concerning the impact of tourism on the regional economy and proposes a number of measures to reform the management of tourism activities at the regional level.
\end{abstract}

Keywords: tourist industry; the tourist potential; regional management of tourism; tourism activities, regional tourism.

Problem statement and its relevance. The development of domestic tourism is impossible without the active promotion of the national Ukrainian tourist product in the domestic market, without the formation of the image of Ukraine as a country favorable for recreation and tourism. The task of promoting Ukrainian regions and original tourist products 
should become a priority at the present time and be carried out on the basis of the following principles:

1) within the framework of joint programs with city and state authorities;

2) year-round, with increased advertising before the holiday seasons;

3) through all existing media: (TV (including specialized channels), radio (advertising and information stories), popular publications, specialized publications (GEO, National Geographic, etc.), business press, Internet (including on the official websites of tourist organizations, targeted information in blogs, social networks);

4) promotion should be carried out in close cooperation with travel agencies.

Analysis of recent researches and publications. The development of the tourism industry in the aspect of a regional approach is reflected in the works T. G. Morozova, S. S. Shilova, K. E. Akhmedkhanova, S. S. Bogdanova, A. Kh. Chupanova, S. S. Israpilova, A.G. Mezentseva, M.D. Dzhamalov. Research of these authors are devoted to the analysis of the investment attractiveness of tourist and recreational resources, development of a set of measures for effective management of the tourism industry, improvement and development of the tourism services market. However, there are still a lot of problems in the tourism industry. In particular, the problems associated with the formation effective tourism management system activities.

The purpose of the article. The aim of the study is to develop theoretical and methodological provisions for the improvement and development of tourist services, assess and management of improving the quality of tourism services to improve the efficiency of the regional tourism industry.

Presentation of the main research material. For the purpose of advertising and information support for the development of domestic tourism in Ukraine, the following are required:

- preparation and creation of a basic package of information and advertising materials on the possibilities of regional tourism in Ukraine;

- participation of regions or private regional tourist organizations in holding international tourism exhibitions in the field of tourism;

- conducting advertising campaigns in the press in order to form a positive image of the regions of Ukraine;

- creation of information banks of data on The Ukrainian travel agencies specializing in the sale of domestic tourist products; 
- creation of a single tourist information network on the territory of Ukraine, its integration with similar international networks;

- formation of a network of regional tourist information centers to create a positive image of Ukraine in the eyes of ukrainians themselves, which has not only economic, but also strategic social meaning.

The promotion of the regions (resorts) of Ukraine is currently constrained by the lack of regional tourist information centers that are actively operating abroad, called tourism offices. The idea of creating tourism offices belongs to France (1890, Grenoble). The basic principles of the activities of French tourism offices are defined in the Law of December 23, 1992 No. $92-1341$ «On the distribution of duties in the field of tourism». Currently, there are more than 25,000 tourism offices in France in all regions of the country, their work is regulated by the Bureau of Tourism and Trade Unions, the National Federation of Tour Operators (all information about the offices can be obtained on the national portal of the www.touuism.fr).

In France, according to the Law «On the Distribution of Duties in the Field of Tourism», the decision to establish a tourism office, as well as the legal justification for its activities, is taken at the level of the local administration. The functions of tourist offices in different countries differ somewhat, but there is one thing in common - their activities are supported by state and local authorities, which are interested in sustainably increasing their tax base at the expense of the tourism industry.

In world practice, extensive networks of tourist offices operating according to generally accepted standards are used as one of the effective mechanisms for collecting and analyzing information on the state of the tourism industry in individual areas and in the country as a whole. In these offices, tourists receive information about local attractions, hotels, excursions and entertainment programs, purchase booklets and maps, theater tickets, books, souvenirs and much more. Based on surveys of office visitors and special studies, analytical reports are compiled annually to assess tourist activity and predict the further development of the industry. These reports are discussed by participants of the tourist market together with representatives of power structures of all levels in order to ensure the competitive positions of their territories.

The task of regional tourist information centers in Ukraine is to ensure the promotion of the territories in which they operate in the domestic and foreign tourist markets. This is possible if there is full information about the participants of the tourist market and the 
services offered by them. The formation of such a database should take place with a clear idea of what kind of information needs to be collected and how to ensure its continuous updating.

Unfortunately, in Ukraine there is currently no constant monitoring of the following information:

- register of existing Ukrainian tourist centers;

- list of tourist services offered on the territory of these centers and in the whole country;

- list of objects of tourist infrastructure with a breakdown by means of accommodation, objects of display and so on;

- statistics of industry development;

- systematic sociological surveys and studies that would give comparable indicators of the dynamics of the development of the tourism sector, and much more.

The lack of well-established schemes, standards for the collection, analysis and provision of information about tourist resorts and services provided in them often leads to an information vacuum not only among consumers of a tourist product, but also among specialists in the field of tourism. This situation against the background of well-established schemes of work with information in the field of tourism business in countries with a developed tourism industry significantly reduces the competitiveness of the Ukrainian tourist product.

In addition, the functions of regional tourist information centers include reception, informing tourists, promoting tourist services, as well as coordinating tourist activities in the territory under their jurisdiction.

Reception, informing tourists and promotion of tourist services are essentially one basic monoservice provided at a time. This function should initially form the basis of the activities of the regional tourist information center, and in the process of expanding its activities, the Center can also coordinate tourism activities in the territory under its jurisdiction.

The local administration may either fully or partially entrust the regional tourist information center with the development of a tourist policy in the territory under its jurisdiction, as well as the creation of programs for the development of tourism, in particular for the creation of a tourist product, the provision of the necessary tourist amenities for recreation in the territory under its jurisdiction, the organization of city holidays and festive processions. 
The study of the potential of the territory, its natural and cultural potential, the existing tourist infrastructure, the list of regional tourist products offered to tourists allows to determine the directions of tourist policy to regional tourist information centers, and also determines their further activities for the development of tourism.

On the basis of such data on the potential capabilities of the territory, it is advisable to form an array of information that can be used by the regional tourist information center when working with tourists:

1) reference information on admission:

- general information on the territory under its jurisdiction, including the history of its creation, as well as information on the region and the country as a whole (translated into several languages);

- various maps and plans of the territory;

- some practical information about the territory as a place for accommodation of tourists, weather forecasts, the condition of roads, etc.

2) advertising information:

- list of existing tourist infrastructure (hotels, restaurants, entertainment, etc., indicating telephone numbers and addresses);

- information on existing tourist services;

- entertainment program for a certain period of time, etc. This information can be presented in a variety of advertising booklets, brochures, catalogs, reference books, memos, postcards, illustrated books.

In addition to existing promotional products, in order to organize the promotion of tourist services, the Centers should also carry out the following activities:

- thematic excursions (in foreign languages);

- provision of paid services (tickets for performances, spa centers, etc.);

- participation in various national and foreign professional exhibitions;

- meetings with representatives of the press and professionals of the tourist business;

- active cooperation with Ukrainian travel companies specializing in domestic and inbound tourism, cooperation with local associations for all kinds of thematic events, such as forums, seminars.

It is advisable that regional tourist information centers include representatives of various organizations: local administration, sponsors, public and private interested organizations. By entering into this public-private partnership, its participants assume the functions of studying, developing and implementing measures to develop the tourist activity 
of the territory, as well as to coordinate tourism activities in the territory under their jurisdiction.

However, when creating regional tourist information centers, there are certain problems - these are their sources of financing, automation of work, lack of standardization of activities.

Abroad, most of, and most often full financing of the work of tourism offices, is undertaken by the state or local administration. In France, for example, the functioning of tourist offices is $80-85 \%$ provided at the expense of budget funds. In Europe, the proportions of financing tourist offices did not arise by chance, since in the process of many years of practice in a market economy, the state and business in the field of tourism act as partners. State and regional authorities provide the information and legal basis for the development of the industry, and private companies, based on this base, provide infrastructure development and income, both for themselves and for local budgets.

There are also a number of other problems that Ukrainian regional tourist information centers will inevitably face in the near future and, as not only world, but also domestic practice shows, the success of their solution will largely depend on state structures of different levels. We are talking about mutually beneficial support, since the activities of local information centers will allow to form a single information space of the tourism industry at the level of individual cities, districts and the country as a whole. And on this basis it will be possible to conduct a serious analysis and make real forecasts of development, both regional tourism and the domestic tourism business as a whole.

Qualitative implementation of such work is possible only when at the state level, in coordination with the leadership of cities, regions and individual regions, certain standards for the activities of regional tourist information centers in the following areas will be formed:

1) their classification, determining the rules of procedure;

2) formation of a list, structure and periodicity of collection of information provided to a potential consumer and administrations of different levels (up to the development of requirements for the preparation of annual reports on the results of tourist activities in the subordinate territory);

3) determination of mechanisms for obtaining and promoting this information for a potential consumer and for administrations of different levels; compilation of a list of requirements for software used in regional tourist information centers; 
4) development of regulatory acts, regulating the activities of regional tourist information centers, including financing from local or regional budgets of their creation and functioning.

Conclusions. When developing Ukrainian standards, it is necessary to take into account the best of the accumulated foreign experience. Such work will contribute to the development of domestic Ukrainian tourism and further interaction of Ukrainian and international information spaces, integration into the sphere of international tourism business.

In modern conditions, the formation of a competitive tourist region is possible only on the basis of creating an integral package of tourist services that meets the needs of a wide range of consumers. Naturally, for the implementation of such projects, the participation of private business, the work of a large number of private, public, mixed, joint firms and organizations that will be engaged in attracting, receiving and servicing tourists with different motivations and requirements are necessary. The creation of regional tourist information centers will allow coordinating and promoting their activities taking into account the interests of all participants. Thus, regional tourist information centers are an associative form of unification of the state and private business to promote the most promising resorts of Ukraine in the state and international tourist markets.

\section{References}

1. Shumlanska N. V. Ecotourism as a form of attachment to the natural and cultural heritage / N. V. Shumlanska // Culture Of Ukraine. - 2014. - № 47. [Electronic resource]. Access mode: http://www.ic.ac.kharkov.ua /RIO/kultura47/15.pdf.

2. Eco and rural tourism: point of intersection [Electronic resource]. - Access mode : https://mykrai.wordpress.com.

3. Ukrainian Association of active and eco-tourism [Electronic resource]. - Access mode: http://uaeta.org/ua/tourism/17.

4. Biletska G. A. Development of ecotourism as a means to economic growth of Khmelnitsky region / G. A. Biletska // Bulletin of the Khmelnytsky National University. 2010. - № 10. - T. 2. - P. 245-247.

5. Lutska N. I. Marketing innovation strategy of development of tourist business. Investments: practice andexperience/ N. I. Lutska, I. Z. Kryxovsky. -2009. - №6. -P. 27-30.

6. Bogush L. G. Ecotourism as a vector of integration of socio-economic and environmental components of sustainable development [Electronic resource] / L. G. Bogush. - Access mode : http://economics-of-nature.net/uploads/arhiv/2008/Bogush.pdf.402. 
7. Ryntziv O.I. Problems of development of ecological tourism in Ukraine // Bulletin of scientific research. Ser.: Tourism / Halych Institute. V. Chornovil. - Ternopil, 2006. - № 1. - P. 180-183.

8. Blackbourne A. A. Regional landscape parks as tourist-and-recreational businesses in the context of sustainable development of tourism in Ukraine / A. A. Blackbourne // Bulletin DMTB : Economics, organization and management of enterprises in the tourism sector. - 2005. - № 9. - P. 190-196.

9. Erchak O. V. Formation of conditions for the development of ecotourism on specially protected natural territories / O. V. Erchak // the ecological and economic mechanism of conservation of biodiversity of especially protected natural territories-Brest : Alternative, 2007. - P. 221-222. 